SANAZ ESTEMADI

Donya Children Research Institute, Tehran, Iran

sanny_e_b@yahoo.com

\title{
CHILD, EDUCATION AND LOVE. CHILD FOCUSSED REFLECTIONS FROM AN IRANIAN PRACTITIONER
}

\begin{abstract}
The following paper is dedicated to theories connecting children, their upbringing and their education with living and working praxis based on love and understanding of children. This is just the first of a series of updates about educational activities of Donya Children Research Institute, based in Tehran (Iran), that will occur as an ongoing feature in Society Register creating a window of communication between 'distant' lands, connected through common interest in children's wellbeing.
\end{abstract}

Keywords: child education; Iran; Donya Children Institute; children's wellbeing.

\section{Introduction}

More than a century has passed from the childhood history and the presence of child in education and in the world of psychology. Who is this child, then? How are they thinking or learning? How does our world of contradictions and complications come to their mind? These are few questions amongst many other ones we should pose on regular basis to reflect and to grow in our practice of working with children and for children.

The important issue in this reflection is the significance of childhood itself. Why is it important to us? Maybe one can say the most important significance of the childhood is in the current situation of our today world which is filled with great new technological developments and in spite of these developments it does not seem to be safe to live in it; civil wars, domestic violence and above all the increasing loneliness are the reason of the necessity of looking again at human being and maybe every individual's childhood. It is axiomatic that this is the most important issue for those who are involved in child affairs and education. In fact, what is the defect in our education? What does lead human to violence and insecurity?

These are the very objectives in the heart of the group at Donya Children Research Institute in Tehran: to provide chances for the children to learn life values, acquire social skills and a universal insight. These objectives could become an inspiring concern for many people. The work of the group is based on several theoretical pillars, that will be discussed further in this paper. Working with the group was an inspiration to gather together theories relevant to their living and working praxis.

Theoretical pillars 
This paper is based on original theories of humanism and the psychological views of this school are studied to realize its proponents' views on social growth. The views of theorists like Gordon W. Allport, Carl Rogers, Eric Fromm, Abraham Maslow and Viktor E. Frankl are among those which are studied in this work. This focus leads us to study humanist psychology school in the light of these four major principles: attention to individual differences, attention to the child needs, recognition of child's talents and ultimately education in life context as the most important pillars of education.

In regard to his career history in Behaviour Psychology and his advocacy of Gestalt theories, after the birth of his first child and his experience of fatherhood, Abraham Maslow made many changes in his view of the education process and studied new pillars.

His belief in human agency and his potential role in improvement of the world is the major factor which could change his research method in his observance of children. He, who believes now in human capabilities, introduced some principles to reach the highest level of humanity.

Capability to make a choice and in some cases freedom of choice: any choice could be an opportunity for the child to express their beliefs and establishment of their self-esteem. These choices can begin in infanthood with the expression of body needs.

Expression of needs: a child can express their needs on the basis of their differences and capabilities. Maybe the role of caretakers is hearing them to help develop these skills as a context to their growth. It is natural that after these means, the child enjoys expressing self. For whoever is around, this expressing of their needs and capabilities is the sign of their development and growth not shortcomings which is present in their life. A child who has a successful experience in expression of their feelings can consider their caretaker a supporter of all their needs like security, love and intimacy. He/she is satisfied with their expression though in some cases needs to be talked with, explained to and even persuaded. All of these are the signs of their satisfaction which is shaped during their life. Ultimately, it is the child who reaches self-growth.

Self-growth: Maslow definition of self-growth is the transition of human characteristics from potential to actual. Since self-growth in human needs time, it is better that its foundation takes place in childhood. Maslow sees human as a growing, dynamic and creative being who is always in pursue of their dignity.

Gordon Allport is another famous psychologist of this kind. His view of human being is very optimistic. The roots of this optimism lie in his advocacy of anthology or living in the moment. Having this view makes him consider a definition of healthy human to be always in pursuit of new experiences and motivated by every moment of life. This view has a moving force for every child to makes them able to do the best. Allport insists very much in theoretical and pragmatic ways to be able to form child's identity. He believes that having respect for children begins from the moment of the childbirth by calling their names. The presence of child's caretakers helps them grow day by day and their support in making joyous and successful opportunities aides the children to find their interests in life. The possibility of a respectful life provides children the chance to learn to be patient and be able to speak at the right moment and respond easily and properly.

Protection of children's privacy is another idea of Allport. It should be kept in mind that every child has privacy. This privacy could be protected, defined and definite by proper and cautious behavior of the parents and ultimately it teaches the child that the others could have privacy too. Those who are familiar to their own privacy cannot easily violate others'. This mutual respect is a way of creating love and intimacy without blind possession. Those 
who have a clear notion of identity and privacy can certainly be sad with or mad at each other but love and actual friendship are realized against this sorrow and violence for which the best time to practice is childhood. Allport maintains that human can observe their capabilities and shortcomings with their created self-esteem. If a child could not do something, they would be able to accept their incapability with the support of caretakers and gradually the rational self of the child takes shape. Those children, who experience their rational self in childhood, face puberty crisis better and suffer less. Sometimes, for getting familiar with their own identity the child needs patient and nonjudgmental caretakers whom in return give themselves the chance to observe someone without any judgment. Through these stages, the child is compared only with themselves and enjoys according to their talents.

Carl Rogers is another theorist who addresses the specifications of caretakers. He believes one could play an effective role in child's life if only they would be able to develop characteristics of a well-informed facilitator around children, provide a chance to direct experience and be aware of boundaries of this experience. He maintains that providing the chance for the children means actualizing their capabilities through the activities which they do according to their needs, abilities and talents.

He believes in expanding child's world and insists on the respect for child's curiosity. He says that the gain of this curiosity makes child discover uncensored and adult's suggestion free world. He believes that a facilitator never thinks for the children and does not love them according to their behavior. He loves them without any condition. This type of approach provides all the kids the chance to use their skills and urges them to distinguish sin from error. He thinks that every human has a right to do wrong and deserve a chance to correct it. In this view, every human has a great responsibility in their actions. It means that everyone is $100 \%$ responsible for their actions. This theory helps the children have a chance to create and experience many different things. Caretakers who fit Roger's profile never have a critical view of children and consequently provide a secure environment for them to give in freely to experiences and love the courage to take action and do not fear to express their thoughts and feelings.

Erik Fromm who had a hard childhood and experienced the World War 2 in his adolescence, asks an interesting question. He, who had been surprised by his associates behavior during the war declared that how come someone who behaves rationally before the war, acts criminally, violently and filled with loath and despise during the war.

Ultimately how much social and historical disasters do affect human behaviors and actions? Fromm believes that society and family play a very great role in one's notion in life. A human being who has a right to lead a healthy life and enjoys a healthy spirit could certainly flourish their talents if a proper chance is present. For Fromm the important point is child's models in life. From the beginning these models take shape in the family that includes parents and caretakers' view of surrounding people. The amount of prejudice and accepting the variety in human being, individual differences, economic and social patterns, religion and ceremonies, all affect the formation of child's personality. Fromm thinks that a human does not live in void. He considers human being as a social entity and in these relationships; formation of human interests could play an effective role in their emotional and social development. Those children whose needs have been acknowledged from infanthood perceive the notion of love properly. Considering these type of needs somehow makes them immune to the future false attachments. It is often seen that the ones who did not receive proper notice and love in childhood, possess a morbid narcissism and cause others suffering in their relationships.

Fromm thinks that growth and development is every human's right. Growth takes shape in childhood. Creating a work could be a chance to this matter. Besides that, getting familiar 
to creative and influential people can increase one's authority and creativity; an authority which its source is the love of life and fellow human beings.

Fromm is an advocate of human relations and connections. He thinks that familiarity and understanding one another precedes any kind of relationship. Being acquainted with nations and cultures can provide us love with awareness; a kind of love that will not be forgotten and increased day by day. All caretakers can increase this love by making themselves more aware of this situation. This education does not have any context but an effective living in current society. When the child begins to explore their surrounding world and love, they protect this section responsibly and considers themselves to be the supporter of this environment.

Victor Frankl is truly worthy of the best sayings about the meaning of life. He reached a gold mine in the direst circumstances... Hope in life, protecting the freedom and human values.

Frankl who spent most of his days in Auschwitz concentration camps had never lost hope. He believed that a human beings are able to decide in a certain moment to change themselves. He said a human being is able to refine sufferings and hardships and present the best of themselves to the world. In his view, human is a free being that can have freedom of choice.

This kind of approach to human enables caretakers to see the world limitless, beautiful and changeable. Children can change their surrounding world if they are aware of their own capabilities and have a chance to experience in life.

Frankl believes that love is not a simple feeling but a process which is chosen by human in their life. In this process, human presence and their consideration to options and possibilities in life play an important role because there is no source for satisfaction with life except love.

Love for life in its turn needs growth and evolution. A part of this need is revealed as the creative imagination. Basically, creativity is specific to childhood spirit if child is given the chance to imagine. It is often this childhood imagination that determines the future gains. Those dreaming children do not fear obstacles in life, and would be ready to solve any problem and love every moment of their lives.

Frankl thinks that everyone can express their love and friendship to others according to the experiences which they have in their lifetime. Giving gifts, being grateful, sympathy and generosity are all the ways of expressing love to others, which are practicable, enjoyable and valuable from the beginning of childhood with support of child's caretakers. When a child is able to recognize his valuable life options and opportunities, they can discuss it with others and somehow share the experience with them.

\section{Final remarks}

After reviewing some notions and ideas of mentioned psychologists it is important to keep in mind that in the whole history of education, all child experts somehow strive for human, life and children (as a part of this life). All of them wished for everyone a healthy psyche and a life filled with peace and comfort and could present theories based on their own experience and mind to improve human life. The shared concerns of these theories are love for life and living humanely, which are rooted in one's inside.

In the course of time, effective teachers like Anton Semenovych Makarenko (1888-1939), Vasyl Olexandrovych Sukhomlynsky (1918-1970) and Janusz Korczak (1878-1942) changed the education system radically and courageously made love their primary objective. They thought more than anything about reforming the education system and they are founders of humanistic values in this system. Maybe their accomplishments are the loving and wise pupils and teachers who can experience teaching the children forever. 
This short paper is an introductory work that aims to show how the theories and beliefs of the 'local' writers are known and adopted globally - in this case followed and embraced in educational praxis in a Persian context. The author of this paper hopes to create further interest of readers in receiving updates about children situation in Iran.

\section{REFERENCES}

Erich, Fromm. 1956. The Heart of man. Its genius for good and evil. New York: Harper\&Row.

Erich, Fromm. 2003. Crisis of psychoanalysis. New York: H. Holt.

Erich, Fromm. 1956. The art of loving. New York: London Continuum.

Erich, Fromm. 1941. Escape from Freedom. New York: Open Road.

Erich, Fromm. 1976. To have or to be? New York, NY: Bloomsbury Academic.

Frankl, Viktor E. 1946. Man's search for meaning. An introduction to logotherapy. New York, NY: Pocket Books.

Nye, Robert D. 1999. Three schools of psychology: Perspectives from Freud, Skinner and Rogers. Boston: Cengage Learning.

Rogers, Carl. 1939. Encounter groups. New York: HarperCollins.

Schultz, Duane P. 2009. Theories of personality. 9th Edition. Belmont, CA: Wadsworth.

Schultz, Duane P. and Sydney E. Schultz 2016. A History of Modern Psychology. 11th Edition. Belmont, CA: Wadsworth.

Woodside, Marianne and Tricia McClam. 2011. An introduction to Human Services. Belmont, CA: Brooks/Cole. 